\title{
Academic Achievement of Adolescents in Relation to Study Habits
}

\author{
Mrs. Reeta Arora $^{1 *}$
}

\section{ABSTRACT}

The purpose of the present study was to find out the relationship between academic achievement and study habits of adolescents. A representative sample of 100 students studying in 9th class was randomly selected from senior secondary schools of Ludhiana district of Punjab (India). Marks obtained by the adolescents in previous annual examination were taken as an index of Academic Achievement .Study Habits Inventory by Dr. N.S Yadav has been used for data collection. Data was analyzed by using t-test and coefficient of correlation. The result indicates that there is a strong positive correlation between academic achievement and study habits of adolescents.

Keywords: Academic Achievement, Adolescents, Habits.

Education is an activity or process, which modifies the behavior of a person from instinctive to human behavior (Taneja, 2003, p.9). This definition reveals the innate truth that education aims at discovering aptitudes as well as to progressively prepare man for social activity; because of this, education through which the basic needs (food, shelter and clothing) are provided is necessary for the survival of the society. The general belief is that students who exercise good study habits are likely to excel than those with poor study habits. According to Sharma (2005, p.67)" academic performance is a necessary evil because one kind of ability is rewarded economically and socially more than others." This necessitates concern over factors that are commonly linked with academic achievement. There is tremendous pressure on students to earn good grades because academic achievement is assumed to possess predictive value and used to bar the gate or to open between the primary, secondary schools and university, and also between the university and certain social professions (Sharma, 2005, p.69)

\section{Academic Achievement}

Academic Achievement generally refers to the degree or level of success or proficiency attained in some academic work. It encourages the students to work hard and learn more. Academic achievement is the status of a student's learning and refers to knowledge attained and skills

\footnotetext{
${ }^{1}$ Asst. Prof., S.D.S College of Education For women, Lopon (India.)

*Responding Author

(C) 2016 I R Arora; licensee IJIP. This is an Open Access Research distributed under the terms of the Creative Commons Attribution License (http://creativecommons.org/licenses/by/2.0), which permits unrestricted use, distribution, and reproduction in any Medium, provided the original work is properly cited.
} 
developed during their academic career which are assessed by school authorities with the help of teacher made or standardized tests.

Academic achievement is one of the most important goals of education. The success or failure of a student is measured in terms of academic achievement. It means development of skills in school subjects. Academic Achievement is the criterion for selection, promotion or recognition in various walks of life. Academic Achievement is based on the assumption that there are differences within an individual from time as behavioural oscillations. The academic achievement of the same individual differs from time to time, from one class to another and from, one educational level to another. Kumari Sushma (2001)-defined academic achievement as the sum total of information gained after completing a course of instruction (partially or fully) in a particular grade that he has obtained on an achievement test. Academic Achievement is one part of the wider term of educational growth. It refers to what a student has achieved in different subjects of studies, during the course of academic year. Academic achievement is affected largely due to the intra individual differences, (differences within the individual from time to time) or with individual differences, i.e. between one individual and another, between one group and another. Besides areas of functioning, individuals of the same group, same grade and same potential ability may differ in their academic proficiency due to many factors. At each stage in the schools some measure of achievement is used as determiner of the student's status and as a basis for decisions about the further opportunities for learning to be provided in subsequent stages. In the present context of education, achievement in academic subjects is the main concern of the teachers, students and parents. The scholastic attainment is the basis of selection and differentiation among students for different openings and avenues of advancement in various fields.

\section{Study Habits}

Study habits have been defined as the sum total of all habits of determined purposes and enforced practices that the individual uses in order to learn. It is necessary for the students to develop special study habits and skills. A well formed habit furnishes its own sources of motivation As such the word 'Study habits' comprised of two words: 'study' and 'habits'. According to English and English, habit is an acquired act, usually relatively simple one that is regularly or customarily manifested and study is relatively protracted application to a topic or problems for the purpose of learning about the topic. Solving the problem or memorizing part or all to the presented material.

Study habits is a well planned and deliberate pattern of study, which has attained a form of consistency on the part of the students towards understanding academic subjects and passing examination (Pauk, 1962; Deese, 1952; Akinboye, 1974 cited by Oyedeji). Therefore, study can be interpreted as a planned program of subject matter master. According to Crow and Crow, (2007), the chief purposes of study are: to acquire knowledge and habits which will be useful in meeting new situations, interpreting ideas, making judgments creating new ideas and to perfect 
skills. Therefore, successful achievement in any form of academic activity is based upon study, interpretation and application. Everyone has different study habits. All often, students perform poorly in school simply because they lack good study habits. In many cases, students do not know where to begin. Those students in high school who succeed especially well usually study alone and follow a study technique that has been worked out by them and that incorporates desirable procedures. Good health, sufficient sleep, appropriate exercise and nutritious diet are essential to achievement of good study results. Study conditions that are unfavorable include inadequate lighting, extremes of temperatures, humidity, poor posture, subnormal physical conditions and emotional disturbance. Although habits differ from person to person, some general principles can be derived about studying efficiently. Here are some good study habits that lead to better academic achievement.

1. Attending classes regularly

2. Taking down notes during teaching

3. Concentrating on study

4. Studying with aim of getting meaning not cramming

5. Preparing a time table

6. Following a time table

7. Having proper rest periods

8. Facing the problems regarding home environment and planning.

9. Facing the challenges posed by school environment

10. Keeping daily survey of work done

Study habits vary from student to student. Some habits are considered to be more desirable than others from the point of view of academic achievement. Crow and Crow (2007, p.261) (ee $^{\text {s }}$ Educational Psychology states that study requires a purpose and what one learns as a result of study depends largely upon the degree to which one succeeds in achieving that aim or purpose. Child (1981, p.95) "s Psychology and the Teacher asserts that we talk about forming bad or good habits in many everyday activities in both social and educational contexts. We behave, by and large, in characteristic ways because we have discovered through experience that some responses are more effective than others.

Sawar et al. (2009) in their analysis on "Study Orientation of High and Low Academic Achievers at Secondary School Level on Pakistan” revealed that the high achievers had better study orientation, study attitude than the low achievers.

\section{NEED AND SIGNIFICANCE OF THE STUDY}

Achievement is the end-product of all educational endeavors. The main concern of all educational efforts is to see that the learner achieves. The distressing phenomena: scholastic underachievement and failure have caused serious concern to educationists, guidance counselors and educational planners for several decades as this amount to colossal wastage of resources available for education. "This necessitates serious probe into the causes that underlie and factors that lead to underachievement and failure, so that means could be devised to grapple with this 
enormous problem (Mishra and Danga 2005).” The failure rate in various examinations may depend on many factors but one of the main reasons is poor or ineffective study habits. Now days students do not devote sufficient time to their studies and seldom have proper study habits. It is felt that students with good study habits are better than others. It is important to have a clear understanding of what benefits or hinders one's educational achievement. This is the premise on which this study is justified

\section{Statement of the Problem}

ACADEMIC ACHIEVEMENT OF ADOLESCENTS IN RELATION TO STUDY HABITS

\section{OBJECTIVES OF STUDY}

The objectives of the study were as follows.

1. To compare the academic achievement of male and female adolescents.

2. To compare the academic achievement of rural and urban adolescents.

3. To compare the study habits of male and female adolescents

4. To compare the study habits of rural and urban adolescents.

5. To find out the relationship between academic achievement and study habits of adolescents.

\section{Hypotheses}

As per the objectives of study, the present study was undertaken to test the following hypotheses.

1. There is no significant difference between academic achievement of male and female adolescents.

2. There is no significant difference between academic achievement of rural and urban adolescents.

3. There is no significant difference between the study habits of male and female adolescents.

4. There is no significant difference between the study habits of rural and urban adolescents.

5. There is no significant relationship between academic achievement and study habits of adolescents.

\section{Design of the Study}

In the present study, descriptive survey method was employed to investigate the relationship between academic achievement and study habits of adolescents.

\section{Sample}

The study was conducted on 100 students (50 boys and 50 girls) of 9th class which were randomly selected from rural and urban senior secondary schools of Ludhiana District. 


\section{Tools Used}

1. Marks obtained by the adolescents in the previous annual examination were taken as an index of Academic Achievement.

2. Study Habits Inventory by Dr. N.S Yadav

\section{Statistical Techniques Used}

Mean, S.D, t-test and Karl Pearson's coefficient of correlation were used for analysis of the data.

\section{ANALYSIS AND INTERPRETATION OF THE DATA}

Table 1, Academic Achievement of Male and Female adolescents

\begin{tabular}{|l|l|l|l|l|}
\hline Category & No. of students & Mean & S.D. & t-ratio \\
\hline Male & 50 & 59.62 & 4.27 & \multirow{2}{*}{7.33} \\
\hline Female & 50 & 68.82 & 7.76 & \\
\hline
\end{tabular}

Significant at 0.01 level

Table 1 shows the mean, standard deviation and t-ratio of academic achievement of male and female adolescents. The calculated mean scores of male and female adolescents are 59.62 and 68.82 respectively. The t-ratio is 7.33 which is significant at 0.01 level. Hence hypothesis there is no significant difference in academic achievement of male and female adolescents stands rejected at 0.01 level.

Table 2, Academic Achievement of Rural and Urban adolescents

\begin{tabular}{|l|l|l|l|l|}
\hline Locale & No. of students & Mean & S.D. & t-ratio \\
\hline Rural & 50 & 61.92 & 5.73 & \multirow{2}{*}{3.089} \\
\hline Urban & 50 & 66.52 & 8.84 & \\
\hline
\end{tabular}

Significant at 0.01 level

Table 2 shows that the mean scores of academic achievement of rural and urban adolescents. The calculated mean scores of rural and urban adolescents are 61.92 and 66.52 respectively .The mean score of urban adolescents is more than that of rural adolescents. The t-ratio is 3.089 that indicates that the difference between the two mean scores is significant at 0.01 level. Hence hypothesis there is no significant difference between academic achievement of rural and urban adolescents stands rejected. 
Table 3, Difference between study habits of male and female adolescents

\begin{tabular}{|l|l|l|l|l|}
\hline Category & No. of students & Mean & S.D. & t-ratio \\
\hline Male & 50 & 214.34 & 18.32 & \multirow{2}{*}{5.40} \\
\hline Female & 50 & 234.72 & 19.36 & \\
\hline
\end{tabular}

Significant at 0.01 level

Table 3 shows that the mean score of study habits of male adolescents is 214.34 with S.D. as 18.32 and mean score of female adolescents is 234.72 with S.D. as19.36. The mean score of study habits of girls is higher than the mean score of study habits of boys. The t-ratio is 5.40 which is significant at 0.01 level. So it is found that study habits of girls are better than the study habits of boys. Hence the hypothesis that there is no significant difference between study habits of male and female adolescents stands rejected at 0.01 statistical level.

Table 4. Difference between study habits of rural and urban adolescents

\begin{tabular}{|l|l|l|l|l|}
\hline Locale & No. of students & Mean & S.D. & t-ratio \\
\hline Rural & 50 & 217.96 & 20.26 & \multirow{2}{*}{3.217} \\
\hline Urban & 50 & 231.1 & 20.589 & \\
\hline
\end{tabular}

Significant at 0.01

Table 4 shows that the mean score of study habits of rural students is 217.96 with S.D. as 20.26 and mean score of urban students is 231.1 with S.D. as 20.589. The mean score of study habits of urban students is higher than the mean score of study habits of rural students. The t-ratio is 3.217 which is significant at 0.01 level. So it can be concluded that study habits of urban student are significantly better than the study habits of rural students. Hence the hypothesis that there is no significant difference between study habits of rural and urban adolescents stands rejected at 0.01 statistical level.

Table 5, Correlation between Academic Achievement and study habits of adolescents

\begin{tabular}{|l|l|l|}
\hline Variable & N & Correlation \\
\hline Academic Achievement & 50 & \\
\hline study habits & 50 & 0.735 \\
\hline
\end{tabular}

Table 5 represents the coefficient of correlation between academic achievement and study habits of adolescents. The value 0.735 indicates that there is positive and highly significant correlation between academic achievement and study habits of adolescents. Hence the hypothesis there is no significant relationship between academic achievement and study habits of adolescents stands rejected.. 


\section{FINDINGS OF THE STUDY}

- There is significant difference between academic achievement of male and female adolescents.

- There is significant difference between academic achievement of rural and urban adolescents.

- There is significant difference between the study habits of male and female adolescents.

- There is significant difference between the study habits of rural and urban adolescents.

- There is significant positive relationship between academic achievement and study habits of adolescents.

\section{CONCLUSION}

In the educational parlance, performance manifests through academic achievement, which is the manifestation of a student's habit of study and they in turn are formed and strengthened through education. The development of good study habits is equally relative and helpful not only in academic work but in career actualization. And because this interrelationship cannot be overlooked, the academic achievement and study habit of the student to a large extent culminates into shaping an individual destiny. Proper study habits should be inculcated and nurtured at the very young age of the child. Efforts should be made both by the parents as well as by the school authorities to provide congenial environment to develop good habits among the children so that academic failure is to be forestalled and standards improved,

\section{REFERENCES}

Azikiwe (1998). Study approaches of University Students, WCCI Region-II Forum, 2, 106-114.

Backer, D.P. (1987). Mother's Strategies for Children School Achievement: Managing the Transition to High School. Sociology of Education, 59, 156-166.

Best JW, Kahn JV (2009). Research in Education. New Delhi: PHI Learning Private Ltd.

Carl, A. Bartling (1988). Longitudinal changes in the study habits of successful college students. Educational and Psychological Measurement. 48(2), 527-535

Child, D. (1981). Psychology and the Teacher. London: Holt, Rinehart and Winston.

Crow DL, Crow A (2007). Educational Psychology. Delhi: Surjeet Publications.

Dinesh, (2003). Study habits of science, arts and commerce students at level of intelligence. M.Ed. Dissertation, Panjab University, Chandigarh

English \& English (1958). A Comprehensive Dictionary of Psychology and Psycho-Analytical Terms.

Good, C.V. (1973). Dictionary of Education. New York: Mc Grew Hill Book Company .Limited.

Koul, Lokesh (1997). Methodology of Educational Research. New Delhi: Vikas Publications.

Mangal, SK. (2008). Advanced Educational Psychology. New Delhi: PHI Learning Private Limited.

Nalini, H.K., Batta Ganesha,H.S.(2009). Study Habits and Students Achievement in Relation to Some Influencing Factors. Edutracks. 9(2). 
Sharma, S.R. (2005). Management of School Organizations. New Delhi: Shri Sai Printographers. Singh, H. (1987). An investigation into the study habits of scheduled caste students in relation to their intelligence and achievement motivation. Journal of the Institution of Educational Research. . 3,25-29.

Taneja, V.R. (2003). Socio-Philosophical Approach to Education. New Delhi: Atlantic Publishers and distributors.

Yadav, N.S. (1976). Study Habits Inventory. Agra Psychological Research Cell. Agra.

Yenagi, G.V. (2006). Study Habits as a Function of Self Perception among Intellectually Gifted and Non-Gifted Students. Journal of Educational Research \& Extension. 9 (2). 